\title{
Measurement and modeling of mercury complexation by dissolved organic matter isolates from freshwater and effluents of a major wastewater treatment plant
}

\author{
Bogdan Muresan $^{\mathrm{a}, 1}$, Benoît Pernet-Coudrier ${ }^{\mathrm{a}, 2}$, Daniel Cossa ${ }^{\mathrm{b}}$, Gilles Varrault ${ }^{\mathrm{a}, \text { * }}$
}

\author{
a Université Paris-Est, LEESU, UMR MA 102, AgroParisTech, Univ. Paris Est Créteil, 61 Av. du Gal de Gaulle, \\ 94010 Créteil Cedex, France \\ b IFREMER Centre de Méditerranée, Lab. de Biogéochimie des Contaminants Métalliques, BP 330, Zone \\ Portuaire de Brégaillon, F.83507 La Seyne-sur-mer, France \\ ${ }^{1}$ Present address: IFSTTAR, Route de Bouaye, BP 4129, 44341 Bouguenais, France. \\ ${ }^{2}$ Present address: Eawag, Überlandstrasse 133, P.O. Box 611, 8600 Dübendorf, Switzerland.
}

*: Corresponding author : Gilles Varrault, Tel./fax: +33 1451716 31/23. ; email address : varrault@u-pec.fr

\begin{abstract}
:
Dissolved organic matter (DOM) samples were obtained from a low-density urbanized area located upstream of Paris (along the Marne River, France) and from the treated effluents at the Paris main wastewater treatment plant. These samples were then fractionated according to their hydrophobicity. DOM fractions consisted of nanomolar to sub-micromolar fresh organic substances with extremely strong $\mathrm{Hg}$-complexing ligands. The conditional stability constants (i.e. $K_{\mathrm{HgL}}^{\prime} ; \mathrm{pH} \sim 6.8, I_{\mathrm{NaCl}}=0.5 \mathrm{M}$, $T=25^{\circ} \mathrm{C}$ ) of the $\mathrm{Hg}$-DOM complexes formed were greater than $10^{24} \mathrm{M}^{-1}$, for the reaction $\mathrm{Hg}^{2+}+\mathrm{L}=\mathrm{HgL}$ (with $\mathrm{L}$ as ligand). For upstream of Paris, thermodynamic calculations indicated that the vast majority of Hg-DOM was associated with hydrophobic DOM. In contrast, in the Paris main wastewater treatment plant effluents, Hg-DOM was mainly bound to hydrophilic DOM. Simple dilution calculations highlighted that due to the large DOM loading of urban discharges, the hydrophilic urban DOM ligands may commonly dominate Hg-DOM speciation in the downstream Seine River, except under extreme dilution (i.e. high water episodes or floods).
\end{abstract}

\section{Highlights}

Treated WWTP effluents were a major source of fresh hydrophilic organic $\mathrm{Hg}$-ligands. Their stability constants $\left(\mathrm{pH} \sim 6.8, I=0.5 \mathrm{M}, T=25^{\circ} \mathrm{C}\right)$ were greater than $10^{24}$. They commonly dominated $\mathrm{Hg}-\mathrm{DOM}$ speciation in the downstream Seine River.

Keywords: Mercury, urban and natural dissolved organic matter (DOM), hydrophobic fractionation 


\section{Common abbreviations}

$\alpha$ : dilution factor

$\beta_{n}$ : stability constants for $\mathrm{HgCl}_{\mathrm{n}}$ (with $\mathrm{n}=2,3$, and 4 )

CLE-SSE: competitive ligand exchange-solvent/solvent extraction

CRM: certified reference material

CV-AFS: cold vapour atomic fluorescence spectrometry

DL: detection limit

DOC: dissolved organic carbon

DOM: dissolved organic matter

F: flow

FTIR: Fourier transformed infrared

$\mathrm{Hg}^{2+}$ : mercuric ion

$\mathrm{Hg}_{\mathrm{D}}$ : total dissolved mercury

HPI: hydrophilic

HPO: hydrophobic

HS: humic substances

$\mathrm{I}_{\mathrm{NaCl}}$ : Ionic strength on $\mathrm{NaCl}$ solutions

$\mathrm{K}^{\prime \prime}$ : conditional stability constants

$\mathrm{K}_{\mathrm{D}}$ : distribution coefficient

$\mathrm{L}$ : binding sites (i.e. ligands) for $\mathrm{Hg}^{2+}$

Py-GC/MS: pyrolysis-gas chromatography and mass spectrometry

Org-S $\mathrm{SED}_{\mathrm{RE}}$ organic reduced sulfur

$\sigma$ : conductivity

SD: standard deviation

SPM: suspended particles matter

$S_{\text {RED }}$ : reduced sulfur (both $S^{-11}$ and $S^{-1}$ )

SRFA: Suwannee river fulvic acid

SRHA: Suwannee river humic acid

SUVA: specific UV absorbance

$\mathrm{T}$ : temperature

TPI: transphilic

WHAM: Winderemere humic aqueous model

WWTP: wastewater treatment plant 


\section{Introduction}

In the aquatic systems, total dissolved mercury $\left(\mathrm{HgT}_{\mathrm{D}}\right)$ is a chemical $\mathrm{Hg}$ species partitioned between inorganic and organic dissolved phases. Dissolved organic matter (DOM) is widely known to form strong complexes with mercuric $\left(\mathrm{Hg}^{2+}\right)$ ions, which in turn influence the $\mathrm{Hg}$ availability for microbial methylation and ultimately the ambient concentrations of monomethylmercury (the most bioaccumulative form of $\mathrm{Hg}$ for aquatic organisms).

Over the past decades, many studies have been published regarding the ability of DOM to complex $\mathrm{Hg}$ in various natural environments (Ravichandran, 2004; Han and Gill, 2005; Khwaja et al., 2006). Laboratory experiments and thermodynamic calculations on $\mathrm{Hg}^{2+}$ complexation by DOM tend to display a wide range of conditional stability constants $\left(K_{\mathrm{HgL}}^{\prime}\right.$ in $\mathrm{M}^{-1}$ ). For example, $K_{\mathrm{HgL}}^{\prime}$ varies from $10^{4.7} \mathrm{M}^{-1}$ to $>10^{32} \mathrm{M}^{-1}$ and, as shown for other cations (Buffle, 1988; Town and Filella, 2000), increases with decreasing Hg:DOM concentration ratios (Yin et al., 1997; Skyllberg et al., 2000). In using DOM isolates and octanol-water partitioning, Benoit et al. (2001) observed that the bulk DOM composition is not an important factor in determining $\mathrm{Hg}^{2+}$ complexation. It was therefore proposed, based on equilibrium experiments (Haitzer et al., 2002) and adsorption model fitting (Drexel et al., 2002), that only a small fraction of low-concentration and high-affinity organic ligands actually dominate $\mathrm{Hg}^{2+}$ complexation at low $\mathrm{Hg}$ loading levels. Studies carried out at low $\mathrm{Hg}$ concentrations indicated that the binding constants for $\mathrm{Hg}^{2+}$ to DOM are on the order of $10^{22}-10^{30} \mathrm{M}^{-1}$ (Lamborg et al., 2003; Hsu and Sedlak, 2003). This is consistent with sulfide and thiols containing ligands (as low-molecular weight compounds or functional groups on DOM). For instance, spectroscopic analyses have revealed that organic reduced sulfur (Org- $S_{\text {RED }}$; i.e. $S_{\text {RED }}$ includes both $S^{-11}$ and $\left.\mathrm{S}^{-1}\right)$ and oxygen/nitrogen (O/N) groups are involved in the complexation of $\mathrm{Hg}^{2+}$ by humic substances (HS) extracted from organic soils (Hesterberg et al., 2001; Xia et al., 1999). Another study on intact organic soils, pointed out the existence of linear two-coordination bonds of $\mathrm{Hg}$ with Org-S $S_{\text {RED }}$ (Skyllberg et al., 2006). Overall, $S_{\text {RED }}$ ligands are minor constituents of organic molecules. Yet, their binding strength towards $\mathrm{Hg}^{2+}$ suggests that most of $\mathrm{Hg}$ in freshwater, estuarine water and coastal seawater is associated with DOM.

Currently, studies that treat Hg/DOM interactions focus on total DOM or dissolved HS of natural origin. Both are predominantly constituted of hydrophobic DOM fraction (HPO). However, in urbanized aquatic systems, as a result of anthropogenic discharges and the strong primary productivity they induce, the contributions of transphilic (TPI) and hydrophilic (HPI) DOM fractions can prevail (Ma et al., 2001; Pernet-Coudrier et al., 2008 and 2010). For instance, during a low-water episode, Pernet-Coudrier et al. (2010) measured that in the Seine River downstream of Paris (France) the HPO fraction only stood for $35 \%$ of the dissolved organic carbon (DOC), whereas up to $45 \%$ of DOC consisted of the HPI fraction. To our knowledge, very little information is available about $\mathrm{Hg}$ / hydrophilic DOM interactions because of the extreme difficulty in isolating this HPI fraction. In their study, Benoit et al. (2001) depicted as HPI fraction what we showed herein to actually be TPI. The first data about HPI fraction showed that it contains numerous proteinaceous substances (PernetCoudrier et al., 2010). Due to its intrinsic enrichment with $\mathrm{N}$ and $\mathrm{S}$, this fraction also presents higher content of binding sites and higher affinity to Pb compared to HPO or HS (PernetCoudrier et al., submitted). Therefore, in order to properly understand the speciation and fate of dissolved $\mathrm{Hg}$ in urbanized aquatic ecosystems, there is a real need to assess the $\mathrm{Hg}$ complexation with urban DOM and its most hydrophilic fraction.

The main objective of this study is to probe the dissolved $\mathrm{Hg}$ complexation and $\mathrm{Hg}$ binding ability of DOM in a heavily urbanized aquatic system, the Seine River (France). To reach this goal and compare with natural DOM, water samples were collected from urban effluents downstream of Paris and from a low impacted site upstream of Paris. Upon isolation, DOM from each site was fractionated according to polarity criteria into hydrophobic (HPO), 
transphilic (TPI) and hydrophilic (HPI) fractions. This enabled to individual characterization of each DOM fraction. Furthermore, a competitive ligand exchange-solvent/solvent extraction (CLE-SSE; Han and Gill, 2005; Gasper et al., 2007) method coupled with dissolved Hg speciation modelling (Tipping, 2007) was employed to determine the conditional stability constants for $\mathrm{Hg}$ complexes with the different DOM fractions. The present work lies within the scope of a larger research effort intended to determine the role of DOM fractions in the binding of trace metals (Buffle et al., 1980; Ravichandran, 1999; Town and Filella, 2000; Herrin et al., 2001) and their transfer to adjacent human communities (Tessier and Turner, 1995).

\section{Sampling sites}

The DOM used herein originated from a sparsely-urbanized river located upstream of Paris (the Marne River at Méry-sur-Marne, $48^{\circ} 58^{\prime \prime} \mathrm{N}, 3^{\circ} 12^{\prime \prime} \mathrm{E}$, January 2007 , France) and from treated effluents within Paris main wastewater treatment plant (the Seine-Aval WWTP at Achères, $48^{\circ} 58^{\prime} \mathrm{N}, 2^{\circ} 10^{\prime} \mathrm{E}$, April 2006). Throughout the text, we will refer to the Méry-surMarne sampling station as "Méry" and the Seine-Aval WWTP sampling station as "WWTP". The Marne River (525 km long, with a catchment basin of $12,660 \mathrm{~km}^{2}$ and average discharge of $110 \mathrm{~m}^{3} \cdot \mathrm{s}^{-1}$ ), located to the east and southeast of Paris, is the main tributary of the Seine River (its average discharge downstream the confluence equals $328 \mathrm{~m}^{3} \cdot \mathrm{s}^{-1}$ ). The Seine-Aval WWTP is located northwest of Paris and collects more than $70 \%\left(1,700,000 \mathrm{~m}^{3}\right)$ of all dry weather (combined sewer) flows in Paris and its suburbs ( 8 million equivalent inhabitants). Until recently, effluent treatments involved a primary settling stage plus aerobic mixing with activated sludge. Since 2007, an additional denitrification and dephosphatation step has been introduced. Depending on the season, the WWTP treated volume of effluents ranges between 2 and $25 \%$ of the local Seine River flow. However, during low water periods, it contributes up to $50 \%$ of the dissolved organic carbon (DOC) downstream of Paris (Meybeck et al., 1998).

\section{Methods}

\subsection{Waters and DOM fractions characterization}

The temperature $\left(\mathrm{T}\right.$, precision of $\left.\pm 0.1{ }^{\circ} \mathrm{C}\right), \mathrm{pH}( \pm 0.01$ unit) and conductivity $\left(\sigma, \pm 0.1 \mu \mathrm{S} \mathrm{cm} \mathrm{cm}^{-1}\right)$ of sampled waters were recorded in situ with a Multi 340i multiparameter probe. The concentrations of $\mathrm{Cl}^{-}, \mathrm{Na}^{+}$and $\mathrm{NO}_{3}{ }^{-}$ions were quantified by photocolorimetry using Spectroquant ${ }^{\circledR}$ kits (Merck, 2011). The concentrations of suspended particulate matter (SPM) were determined by weight difference of $0.45 \mu \mathrm{m}$ pore-size dried filters $\left(\mathrm{LCR}^{\circledR}\right.$, Millipore) before and after filtration. Finally, samples for organic $C$ in unfiltered and dissolved phases were analysed by IR spectroscopy after oxidative or acidic digestion of the samples.

The details about isolation and characterization of the Seine DOM fractions were previously reported (Pernet-Coudrier et al., 2008 and 2010). In summary, the surface water was in-line filtered through subsequent 10 and $0.45-\mu \mathrm{m}$ polypropylene filters, softened on a cationic exchange resin and concentrated using a field reverse osmosis device. The $50-\mathrm{L}$ stainless steel drums used to collect the concentrate were previously cleaned with ultrapure water ( $\rho$ $>18.2 \mathrm{M} \Omega \mathrm{cm}$ ). The concentrate was then passed through DAX-8 and XAD-4 resin columns to obtain the HPO and TPI fractions, respectively. The HPI, i.e. the fraction of DOM not retained by DAX- 8 and XAD-4 resins, was separated from the inorganic salts by means of zeotrophic distillation, successive salt precipitation and trapping on cationic exchange resin. Finally, the eluates were freeze-dried and stored for later use. All the glassware and 
materials involved in DOM fractionation and purification were washed with detergent (TFD4, $5 \%$ ), then rinsed with ultrapure water and precombusted for $5 \mathrm{~h}$ at $500^{\circ} \mathrm{C}$.

The DOM fractions have been thoroughly characterized using multiple analytical techniques (e.g. elemental composition analyses, FTIR and UV spectroscopy, size exclusion chromatography, Py-GC-MS, etc.) and obtained data were previously reported (Filella et al., 2009, Pernet-Coudrier et al., 2008 and 2010). Here, since $\mathrm{Hg}^{2+}$ ions have a very high affinity for $S_{R E D}$ ligands, the proportions of total organic $S$ in the form of Org- $S_{R E D}$ were estimated using online coupling of pyrolysis-gas chromatography and mass spectrometry (Py-GC-MS). The procedure is discussed in Olivella et al. (2002). Briefly, Org- $S_{\text {RED }}$ contents of DOM samples have been indirectly estimated through the relative area of sulfidic and thiophenic peaks in the chromatogram of the pyrolyzer's outlet gas. It is worth noting that obtained values can only be taken as rough indicators of the Org- $S_{\text {RED }}$ contents of DOM since: i) the organic molecules de/recompose during the pyrolysis step and ii) the relative contributions of pyritic and sulfate forms might casually be important. These qualitative data were completed for SRFA and SRHA reference materials using the available values in the literature (Haitzer et al., 2003). Some selected characteristics are given in Table 1.

\subsection{Mercury sampling and determination}

The ultra clean sampling techniques and analytical methods applied for $\mathrm{Hg}$ analyses in water are those described and discussed in detail by Bloom (1989) and Cossa et al. (2002, 2003). Samples were collected in acid-cleaned Teflon (FEP) bottles. Polyethylene gloves were used for handling operations. Water filtrations were performed in-situ within the first minutes of collection through $0.45 \mu \mathrm{m}$ membranes ( $\mathrm{LCR}^{\circledR}$, Millipore). Samples were then acidified to $0.5 \%(\mathrm{v} / \mathrm{v})$ with $\mathrm{HCl}$ (Suprapur ${ }^{\circledR}$ grade reagents from Merck). Bottles were capped, double bagged then stored at $+4^{\circ} \mathrm{C}$ in the dark until analysis.

All $\mathrm{Hg}$ species were quantified using cold vapour atomic fluorescence spectrometry (CV$\mathrm{AFS}$ ). $\mathrm{Hg}_{\mathrm{D}}$ was determined according to the Bloom and Fitzgerald technique (Bloom and Fitzgerald, 1988), through formation of volatile elemental $\mathrm{Hg}$ in a Teflon (PFA) reactor (released by $\mathrm{SnCl}_{2}$ reduction, after 30 minutes of acidic $\mathrm{BrCl}$ oxidation) and preconcentration on a gold trap. Used chemicals were of analytical grade and met the specifications of the American Chemical Society for trace metal measurements. The detection limits (DL), defined as 3.3 times the standard deviation of the blanks, typically equalled $0.05 \mathrm{pM}$. The analysed sample volume was between 50 and $100 \mathrm{~mL}$. The relative standard deviation, calculated on five replicate samples to be approximately $0.5 \mathrm{pM}$, was less than $10 \%$. The mean recovery and variance associated with the $\mathrm{HgT}_{\mathrm{D}}$ determination accuracy were $93 \pm 5 \%$, (average \pm $\mathrm{SD}$ ) and this figure was regularly checked using the reference material (ORMS-3) from the National Council of Canada as a certified reference material (CRM). The detailed procedure has been provided by Cossa et al. (2003).

\subsection{Numerical simulations of titrations and environmental impacts}

Preliminarily to the experimental work, the speciation program Winderemere Humic Aqueous Model (WHAM 6; Tipping, 2002) was used to simulate the competition between chlorides and DOM for $\mathrm{Hg}^{2+}$ binding. This permitted to gauge the concentrations of chlorides to be used in the titration experiments. For instance, the WHAM 6 program indicated that at $\mathrm{pH} \sim$ $6.8, \mathrm{I}_{\mathrm{NaCl}}=0.5 \mathrm{M}, \mathrm{T}=25^{\circ} \mathrm{C}$ and in the presence of $1 \mu \mathrm{g} \mathrm{L}^{-1} \mathrm{DOM}$ (the titrations were conducted without any added buffer to keep the interfering ligands level low) $\mathrm{Hg}$ shifts from $\mathrm{DOM}$ to chloride complexes while increasing $\left[\mathrm{HgT}_{\mathrm{D}}\right]$. Another application was the appraisal of mineral $\mathrm{Hg}$ complexes that control inorganic $\mathrm{Hg}$ distribution between aqueous and organic titration phases: i.e. calculations predicted that at $\mathrm{pH} \sim 6.8, \mathrm{I}_{\mathrm{NaCl}}=0.5 \mathrm{M}, \mathrm{T}=25^{\circ} \mathrm{C}$ and in the absence of DOM, chloride $\mathrm{Hg}$ complexes were predominant $\left(>99 \%\right.$ of $\mathrm{HgT}_{\mathrm{D}} ; \mathrm{HgCl}^{+}<<1 \%$, $\mathrm{HgCl}_{2}<5 \%, \mathrm{HgCl}_{3}{ }^{-}<20 \%$ and $\mathrm{HgCl}_{4}{ }^{2-}>75 \%$ ). Finally, to evaluate the environmental impact 
of discharged urban DOM fractions on $\mathrm{HgT}_{\mathrm{D}}$ speciation in the downstream from WWTP, the WHAM 6 program was implemented with experimentally determined $K_{\text {HgL }}^{\prime}$ and [L] (i.e. the strong binding sites for $\mathrm{Hg}^{2+}$ that constitute a few percent of the DOM fractions) values. This allowed to thermodynamically simulate Hg-DOM partition between urban and natural DOM during WWTP effluents dilution with riverine waters like Méry's, The inputs were the $\mathrm{pH}$ and $\left[\mathrm{HgT}_{D}\right]$, major ions such as $\left[\mathrm{Cl}^{-}\right]$and $\left[\mathrm{Na}^{+}\right]$as well as the concentrations of every single DOM fraction or reference materials. The formation constants recommended by the National Institute of Standards and Technology (NIST 2004) and Powel et al. (2005) for $\mathrm{Hg}^{2+}$ complexation with $\mathrm{OH}^{-}, \mathrm{Cl}^{-}$and $\mathrm{NO}_{3}^{-}$were used to update WHAM 6 database. The intrinsic equilibrium constants for organic $\mathrm{Hg}$ complexes used in calculations were those estimated by Tipping (2007).

\subsection{CLE-SSE titrations}

Aqueous solutions of $20 \mathrm{~mL}$ ultrapure water containing $\mathrm{Hg}\left(\mathrm{NO}_{3}\right)_{2}(5-100 \mathrm{pM})$ and $0.5 \pm 10^{-6}$ $\mathrm{M}$ chlorides were shaken for $3 \mathrm{~h}$ in Teflon flasks for purposes of equilibration. All the chemicals used in CLE-SSE titrations were of analytical or Suprapur ${ }^{\circledR}$ grades. The inorganic mixtures were then spiked with stock DOM solutions to reach final concentration of $1 \mu \mathrm{g}_{\mathrm{DOM}} \mathrm{L}^{-}$ 1 . These were prepared by dissolving known weights of freeze-dried fractionated DOM or commercial HS purchased from the International Humic Substances Society (SRHA ref. $2 \mathrm{~S} 101 \mathrm{H}$ humic and SRFA ref. 2S101F fulvic acids) as well as from Fluka chemical company (Fluka humic acid) in ultrapure water. These commercial substances were used as reference materials in order to compare their conditional stability for $\mathrm{Hg}$ complexes with that of the fractionated DOM. The mixtures were then shaken for a 15-h period: the equilibrium time was tested for each DOM fraction in preliminary experiments by measuring the net reactive $\mathrm{Hg}$ decay. Next, an equal volume of methylene chloride was introduced and the mixtures were shaken for an additional $3 \mathrm{~h}$. Aliquots $(18 \mathrm{~mL})$ from the aqueous phases were treated with acidified $\mathrm{BrCl}$ for $24 \mathrm{~h}$ to measure $\mathrm{HgT}_{\mathrm{D}}$, while the remaining $2 \mathrm{~mL}$ were used for $\mathrm{pH}$ determinations. The methylene chloride phases containing most of the Hg-DOM compounds were transferred into ultrapure water by evaporating the organic solvent before performing the analytical procedure described above. Extraction efficiency of Hg-DOM into methylene chloride $(90 \%-95 \%)$ and ensuing corrections were quantified for each single sample. These figures were initially assessed in the presence of $1 \mu \mathrm{g} \mathrm{L}^{-1} \mathrm{DOM}$ by measuring $\mathrm{HgT}_{\mathrm{D}}$ in the inorganic and organic phases to which no competing chloride ligands were added. Direct $\mathrm{HgT}_{\mathrm{D}}$ measurements in both phases resulted in quantitative recoveries (always above $90 \%$ ). Both the method and procedural blanks remained below DL.

Details on the CLE-SSE procedure and its underlying theory are included in Han and Gill (2005). Briefly, the CLE-SSE technique employs two competitive ligands, here chlorides and DOM, followed by water-methylene chloride extraction to separate the charged chloride $\mathrm{Hg}$ complexes (e.g. $\mathrm{HgCl}^{+}, \mathrm{HgCl}_{3}{ }^{-}, \mathrm{HgCl}_{4}{ }^{2-}$ ) from the neutral and organic $\mathrm{Hg}$ complexes (e.g. $\mathrm{HgCl}_{2}$ and $\mathrm{Hg}$-DOM). The $K_{D}$ for $\mathrm{HgCl}_{2}$ (with $K_{D}\left(\mathrm{HgCl}_{2}\right)=\left[\mathrm{HgCl}_{2}\right]_{\mathrm{Org}}:\left[\mathrm{HgCl}_{2}\right]_{\mathrm{Aq}}=1.5 \pm 0.4$ ) was assessed by measuring [ $\mathrm{HgT}_{\mathrm{D}}$ ] in both aqueous (Eq. 1) and organic (Eq. 2) phases to which no DOM was added:

$$
\begin{gathered}
{\left[\mathrm{HgCl}_{2}\right]_{\mathrm{Aq}} \approx \frac{\left[\mathrm{HgT}_{\mathrm{D}}\right]_{\mathrm{Aq}}}{1+\left(\beta_{3} / \beta_{2}\right)\left[\mathrm{Cl}^{-}\right]+\left(\beta_{4} / \beta_{2}\right)\left[\mathrm{Cl}^{-}\right]^{2}}} \\
{\left[\mathrm{HgCl}_{2}\right]_{\text {Org }} \approx\left[\mathrm{HgT}_{\mathrm{D}}\right]_{\mathrm{Org}}}
\end{gathered}
$$

where $\beta_{n}$ (with $n=2,3$, and 4 ) are the stability constants for $\mathrm{HgCl}_{n}\left(\beta_{2}=10^{14.0}, \beta_{3}=10^{15.0}\right.$, and $\beta_{4}=10^{15.6}$ at $I_{\mathrm{NaCl}}=0.5 \mathrm{M}$ and $\mathrm{T}=25^{\circ} \mathrm{C}$ ) and the subscripts "Aq" and "Org" stand for aqueous and organic phases, respectively. Calculations ignored the contributions of ultratrace $\mathrm{Hg}$ complexes (e.g. $\mathrm{HgCl}^{+}, \mathrm{ClHg}(\mathrm{OH})$, etc.). The low organic phase $\left[\mathrm{HgT}_{\mathrm{D}}\right]$ 
confirmed that: i) the contamination of samples with organic substances was unlikely, ii) the charged chloride $\mathrm{Hg}$ complexes did not significantly partition into methylene chloride (i.e. $K_{D}$ $<510^{-2}$ ) and iii) the obtained figures were consistent with WHAM 6 calculations indicating that at $\left.0.5 \mathrm{M}^{-} \mathrm{Cl}^{-}\right]$the fraction of inorganic $\mathrm{Hg}$ present as $\mathrm{HgCl}_{2}$ did not exceed $5 \%$ (see Section 3.3). Hence, in the presence of every single DOM fraction, $\left[\mathrm{Hg}^{2+}\right]$ was calculated using $\beta_{n}$ with the measured $\left[\mathrm{HgT}_{\mathrm{D}}\right]$ and $\left[\mathrm{Cl}^{-}\right]$in the aqueous phase. Once $\left[\mathrm{Hg}^{2+}\right]$ obtained, the concentration of $\mathrm{Hg}$-ligand complexes (i.e. $[\mathrm{HgL}]$ ) was calculated using the experimentally determined $K_{D}\left(\mathrm{HgCl}_{2}\right)$ and $\left[\mathrm{HgT}_{D}\right]$ of the organic phase. Finally, $K_{\mathrm{HgL}}^{\prime}$ and [L] were determined from titration data using the slope and the intercept of the Van den Berg/Ruzic linearization of the Langmuir isotherm equation:

$$
\frac{\left[\mathrm{Hg}^{2+}\right]}{[\mathrm{HgL}]}=\frac{\left[\mathrm{Hg}^{2+}\right]}{[\mathrm{L}]}+\frac{1}{\mathrm{~K}_{H g L}^{\prime}[\mathrm{L}]}
$$

Since linearization can lead to increased errors at high concentration ranges (as the nonlinear shape of curves in Fig. 1 suggested), slope and intercept calculations were restricted to $\left[\mathrm{Hg}^{2+}\right]<10^{-24} \mathrm{M}$. In this titration window of strong $\mathrm{Hg}$-binding strength ligands, the shape of curves was close to linearity $\left(r^{2}>0.96\right)$ and therefore the Van den Berg/Ruzic linearization of the Langmuir isotherm equation was locally effective. Furthermore, the structure of errors upon linearization remained relatively unchanged ( $<3 \%$ of variation). Uncertainties on gained $K_{\mathrm{HgL}}^{\prime}$ and $[\mathrm{L}]$ values primarily reflected the accuracy of $\left[\mathrm{HgT}_{\mathrm{D}}\right]$ determinations within the $5-100$ pM interval (typically $<5 \%$ ). Overall, using least squares regression at a $95 \%$ confidence level, these were $<10 \%$ in determining $[\mathrm{L}]$ and roughly $2-3 \%$ in determining $\log _{K_{\mathrm{HgL}}^{\prime}}$.

\section{Results}

\subsection{Physico-chemical properties of sampled waters}

On the day of the sampling, the surface waters from Méry displayed the following physical variables and concentrations of dissolved constituents (average $\pm S D ; n=5$ samples): flow $(\mathrm{F})=80 \pm 15 \mathrm{~m}^{3} \mathrm{~s}^{-1} ; \mathrm{T}=7 \pm 2{ }^{\circ} \mathrm{C} ; \mathrm{SPM}<1 \mathrm{mg} \mathrm{L}^{-1} ; \mathrm{pH}=8.5 \pm 0.2 ; \sigma=560 \pm 30 \mu \mathrm{cm}^{-1}$ and DOC $=2.0 \pm 0.2 \mathrm{mgC} \mathrm{L}^{-1}$. Comparatively, at the sampled WWTP discharge point, in the absence of denitrification and dephosphatation step, the treated effluents from WWTP had the following characteristics: $\mathrm{F}=20 \pm 3 \mathrm{~m}^{3} \cdot \mathrm{s}^{-1} ; \mathrm{T}=17 \pm 1^{\circ} \mathrm{C} ; \mathrm{SPM}=50 \pm 1 \mathrm{mg} \mathrm{L}^{-1} ; \mathrm{pH}=7.8$ $\pm 0.2 ; \sigma=1,580 \pm 70 \mu \mathrm{S} \mathrm{cm}{ }^{-1}$ and $\mathrm{DOC}=38.7 \pm 0.2 \mathrm{mgC} \mathrm{L}^{-1}$.

\subsection{Physico-chemical properties of DOM fractions}

In recent studies (Pernet-Coudrier et al., 2008; Filella et al., 2009; Pernet-Coudrier et al., 2010), the composition, structure and functional groups of isolated DOM fractions have been thoroughly investigated using multiple analytical techniques (e.g. elemental composition analyses, FTIR and UV spectroscopy, size exclusion chromatography, Py-GC-MS, etc.). The DOM fractions from WWTP displayed marked hydrophilic traits (i.e. low HS contents, low SUVA) along with a high degree of heterogeneity and low average molecular weight. Besides, FTIR, fluorescence and Py-GC-MS measurements indicated that relatively to the Méry fractions and the SRFA, the DOM fractions from WWTP contained higher amounts of proteinaceous structures. This justifies the fact that their $\mathrm{N}$ and $\mathrm{S}$ compositions were especially high whereas their $\mathrm{O}$ compositions were relatively lower (Table 1). 


\subsection{Sulfur in the isolated DOM fractions}

Sulfur represented a minor constituent of the DOM fractions (Table 1). The total $S$ compositions were $680-1,260 \mathrm{nmol} \mathrm{mgC}^{-1}$ in the DOM fractions from Méry and reached $1,330-1,520 \mathrm{nmol}^{\mathrm{mgC}^{-1}}$ in the DOM fractions from WWTP (Table 1). The Org-S $\mathrm{S}_{\text {EED }}$ constituted $7 \%-11 \%$ of the total $S$ compositions in the fractions from Méry and $14 \%-22 \%$ in the fractions from WWTP. Overall, Org-S $S_{\text {RED }}$ contents within the HPO and TPI were $50 \%$ higher than Org-S $S_{\text {RED }}$ contents within HPI. These results were similar to the data for bulk DOM found in the literature (Benoit et al., 2001; Qian et al., 2002; Haitzer et al., 2003).

Total S compositions of SRFA, SRHA and Fluka reference materials amounted to: $325 \pm 20$,

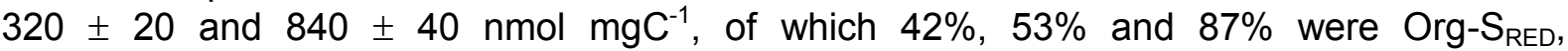
respectively. These values are in accordance with data from Morra et al. (1997) and Haitzer et al. (2003).

\subsection{Mercuric ion binding by DOM fractions}

At $\mathrm{pH} \sim 6.8, \mathrm{I}_{\mathrm{NaCl}}=0.5 \mathrm{M}, \mathrm{T}=25^{\circ} \mathrm{C}$ in the presence of $1 \mu \mathrm{g} \mathrm{L}^{-1}$ of DOM fractions from Méry, Log $K_{\text {HgL }}^{\prime}\left(\right.$ and L) averaged $24.6 \pm 0.3\left(41.1 \pm 0.6 \mathrm{nmol} \mathrm{mgC}^{-1}\right)$ and equaled $24.7 \pm 0.1(52.4 \pm$ $\left.0.3 \mathrm{nmol} \mathrm{mgC} \mathrm{ma}^{-1}\right)$ in the HPO, $24.4 \pm 0.1\left(19.2 \pm 0.2 \mathrm{nmol} \mathrm{mgC}^{-1}\right)$ in the TPI and $24.2 \pm 0.1$ $\left(9.1 \pm 0.1 \mathrm{nmol} \mathrm{mgC}^{-1}\right)$ in the HPI, respectively (Fig. 1; Table 1). From [DOC] of each fraction in the rough Mery sample, the total organic ligand concentration averaged $78 \pm 7 \mathrm{nM}$ (of which $90 \%$ were hydrophobic). At WWTP, Log $K_{\text {HgL }}$ (and L) in DOM averaged $25.3 \pm 0.3$ $\left(33.5 \pm 0.7 \mathrm{nmol} \mathrm{mgC}^{-1}\right)$ and equaled $25.4 \pm 0.1\left(18.7 \pm 0.2 \mathrm{nmol} \mathrm{mgC}^{-1}\right)$ in the HPO, $25.1 \pm$ $0.1\left(50.1 \pm 0.1 \mathrm{nmol} \mathrm{mgC}^{-1}\right)$ in the TPI and $25.3 \pm 0.1\left(37.2 \pm 0.4 \mathrm{nmol} \mathrm{mgC}^{-1}\right)$ in the HPI, respectively. In the rough effluent sample, total organic ligand concentration averaged 1,210 $\pm 90 \mathrm{nM}$ (of which $80 \%$ were divided between the TPI and HPI fractions).

\section{Discussion}

\subsection{DOM maturity and hydrophobicity}

For a detailed understanding of the elemental data, the C:N molar ratios have been plotted against the C:S molar ratios (Fig. 2a). Due to the preferential loss of $S$ groups and the relative carbon enrichment during natural decomposition processes, the increase of C:S ratio values reflected the increasing maturity of the material (Aiken et al., 1996). Accordingly, the maturated SRFA and SRHA samples have been associated with high C:S ratios (i.e. 255260), whereas the values for the DOM fractions from Méry and WWTP were significantly lower: i.e. 70-120 and 55-63, respectively. This result supported that the fractionated DOM from the Seine Basin mainly consisted of fresh organic substances. This could be explained at Méry by the contribution of algal and plant-derived debris, and at WWTP by the presence of both anthropogenic- (i.e. from proteins and lipids) and microbial- (i.e. from bacterial cell walls) derived sulfur-containing compounds. This is in agreement with isotopic $\left({ }^{13} \mathrm{C}\right.$ and $\left.{ }^{15} \mathrm{~N}\right)$ and SUVA and C/H ratio published by Pernet-Coudrier et al., (2010).

The terrestrial organic matter is relatively depleted in N (Ruttenberg and Goñi, 1997). Hence, increased $\mathrm{C}: \mathrm{N}$ ratio values likely reflected the increasing contributions of terrestrially-derived DOM molecules. In effect, $\mathrm{C}: \mathrm{N}$ ratio values clearly increased with the hydrophobicity of DOM according to the following sequence: $\mathrm{HPI}_{\text {WWTP }}<\mathrm{TPI}_{\text {WWTP }}<\mathrm{HPO}_{\text {WWTP }}<\mathrm{TPI}_{\text {Méry }}<\mathrm{HPO}_{\text {Méry }}<$ SRHA < SRFA < Fluka humic acid (Table 1, Fig. 2a). The highest value was found for the Fluka humic acid ( $\mathrm{C}: \mathrm{N}=89$ ), which consists of highly hydrophobic humic acids of terrestrial origin. Furthermore, the increase of DOM hydrophobicity, as observed in the C:N sequence, 
was positively correlated with the proportion of total organic $S$ in the form of Org-S RED $\{p=$ $0.05, r^{2}=0.90$; Org-S RED $\left.: S(\%)=0.8 \mathrm{C}: \mathrm{N}+4\right\}$ (Fig. 2b). On the basis of published $\mathrm{S}$ speciation in microbial biomass and in most animal- and plant-derived proteins (Lehninger, 1985), it is possible for $S$ within DOM functional groups and constituents (e.g. cystine from keratins or other fibrous insoluble proteins) to be enriched in $S_{R E D}$ in the most hydrophobic DOM samples (like SRFA or SRHA; Table 1).

\subsection{DOM aging and variability}

Figures $3 a$ and $3 b$ indicated that $\log K_{H g L}^{\prime}$ is positively correlated with total organic $N\{p=$ $\left.0.05, r^{2}=0.50 ; \log K^{\prime}{ }_{H g L}=4 \cdot 10^{-5} \mathrm{~N}\left(\mathrm{nmol}^{\prime} \mathrm{mgC}^{-1}\right)+24.5\right\}$ and $S\left\{p=0.05, r^{2}=0.60 ; \log K^{\prime}{ }_{H g L}\right.$ $\left.=10^{-3} \mathrm{~S}\left(\mathrm{nmol} \cdot \mathrm{mgC}^{-1}\right)+24.0\right\}$ compositions. $\mathrm{N}$ - and S-enriched organic materials, like the fresh DOM fractions from WWTP, conveyed stronger Hg-complexing ligands (i.e. Log $K_{\text {'HgL }}$ $>25.0$ ). We therefore assumed that DOM could undergo an aging process making strong binding sites less available for $\mathrm{Hg}^{2+}$ complexation. Aging seemingly occurred during DOM maturation $\left\{p=0.05, r^{2}=0.64 ; \log K_{H g L}^{\prime}=-0.01 \mathrm{C}: S+25.50\right\}$ and corresponded to the sum of structural transformations (Buffle, 1988), like degradation (breakthrough of the most labile moieties such as amino and fatty acids) and condensation (cyclization of the aliphatic chains and development of aromatic structures). If correct, in spite of their higher $L$ contents (Table 1), the matured DOM like the SRFA and SRHA should less strongly bind $\mathrm{Hg}^{2+}$. The SRFA and SRHA consisted of the fulvic and humic acids from the black-water river draining the Okeefenokee Swamp (USA), respectively. They exhibited highest L compositions (324 and $61 \mathrm{nmol} \cdot \mathrm{mgC}^{-1}$, respectively); Hg-binding sites content of SRFA exceeded that of Org-S $\mathrm{S}_{\mathrm{RED}}$. Yet, as expected, these organic acids also displayed lower Log $K_{H g L}^{\prime}$ values (22.8 \pm 0.3 and $24.4 \pm 0.1$, respectively) than the fresh DOM from WWTP.

In regard to the variability of strong organic ligand, the binding strength towards $\mathrm{Hg}^{2+}$ was more pronounced for DOM of a different origin, either Méry or WWTP, than it was for the various fractions (HPO, TPI or $\mathrm{HPI}$ ) (Table 1). It thus appeared that for $\mathrm{Hg}$ the distinction between DOM of different origins was more fundamental than that resulting from the use of a fractionation method. On the one hand, the origin of the solubilized terrestrial organic matter (e.g. soil organic compounds, plant litter, anthropogenic wastes), as well as that of the aquatic organic molecules comprising DOM, controlled the initial amounts and varieties of functional groups for strong $\mathrm{Hg}^{2+}$ binding (such as reduced $\mathrm{S}$ and $\mathrm{N}$ heteroatoms). While on the other hand, the isolation protocol enabled DOM fractionation on polarity criteria, i.e. mixtures of compounds showing analogous polar bonds and/or arrangements of their nonpolar covalent bonds and non-bonding full molecular orbitals. Therefore, the minute amounts of Org- $S_{\text {RED }}$-containing ligands appeared to be more vital than the gross chemical compositions (i.e. the presence or absence of proteins, sugars, aromatic or aliphatic chains, etc. capable of affecting DOM hydrophobicity) in explaining the ability of DOM to strongly bind $\mathrm{Hg}^{2+}$. For instance, when the different DOM fractions from Méry (or WWTP) were

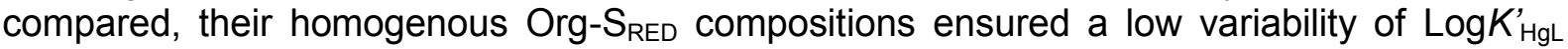
(i.e. $\Delta$ Log $K_{\text {HgL }}^{\prime}<0.5$ units). However, when similar DOM fractions from Méry and WWTP were compared, the latter, whose Org- $S_{R E D}$ compositions were significantly higher, exhibited characteristically higher $\log K^{\prime}{ }_{\mathrm{HgL}}$ values (i.e. $\Delta \mathrm{Log} K^{\prime}{ }_{\mathrm{HgL}}>0.7$ units). It is worth noting that, unlike for $\mathrm{Hg}$, the first results about $\mathrm{Cu}, \mathrm{Pb}$ and $\mathrm{Zn}$ complexation by $\mathrm{DOM}$ highlighted substantial variability upon hydrophobic fractionation

\subsection{Environmental aspects}

The CLE-SSE procedure with chlorides (i.e. a weak $\mathrm{Hg}^{2+}$ binding species), ignored the potential contribution of a small fraction of extremely strong $\mathrm{Hg}$-complexing organic ligands (of $K_{\mathrm{HgL}}^{\prime} \gg 10^{26} \mathrm{M}^{-1}$ ). However, within the chlorides detection window, it allowed consistent comparison between DOM fractions. Hence, from $K_{\mathrm{HgL}}^{\prime}$ and [L], and assuming that [L] >> 
[HgL], the proportions of $\mathrm{Hg}$ associated with HPO, HPI and TPI fractions were calculated as follows:

$$
\frac{[\mathrm{Hg}-\mathrm{HPO}]}{[\mathrm{Hg}-\mathrm{HPI}]} \approx \frac{\left[\mathrm{L}_{H P O}\right] \mathrm{K}_{H g-H P O}^{\prime}}{\left[\mathrm{L}_{H P I}\right] \mathrm{K}_{H g-H P I}^{\prime}}
$$

At $\mathrm{pH} \sim 6.8, \mathrm{I}_{\mathrm{NaCl}}=0.5 \mathrm{M}$ and $\mathrm{T}=25^{\circ} \mathrm{C}$, the $\mathrm{Hg}-\mathrm{DOM}$ from Méry consisted of $94 \pm 7 \% \mathrm{HPO}, 5$ $\pm 1 \% \mathrm{TPI}$ and $0.7 \pm 0.5 \% \mathrm{HPI}$. At WWTP, these were $25 \pm 3 \% \mathrm{HPO}, 22 \pm 2 \% \mathrm{TPI}$ and $53 \pm$ $4 \%$ HPI. Additional WHAM 6 simulations showed that the partitions remained relatively unchanged up to $10 \mathrm{nM} \mathrm{HgL} \mathrm{(}<5 \%$ variation). This highlighted a fundamental distinction between natural (mostly hydrophobic) and urban (predominantly hydrophilic) Hg-DOM. On the one hand, hydrophobic Hg-DOM molecules would adsorb on suspended solids and partly be transferred towards the sediments. On the other hand, hydrophilic Hg-DOM molecules may durably remain into the water column. Further researches are therefore needed to assess the importance of hydrophilic Hg-DOM interactions with suspended solids and/or their direct transferred towards the aquatic organisms.

As the effluents from WWTP were diluted with riverine waters like Méry's, the Hg-DOM partition likely shifted from urban hydrophilic to natural hydrophobic ligands. Hence, the HgDOM partition between urban and natural DOM was estimated at increasing dilution factors (i.e. $\alpha$ ) (Table 2). The calculations assumed that at environmental $\left[\mathrm{Hg}_{\mathrm{D}}\right]$ levels (i.e. $<10 \mathrm{nM}$ ) the contribution of inorganic $\mathrm{Hg}$ ligands in these oxygenated waters was negligible (Ravichandran, 2004; Miller et al., 2007 and 2009; Dong et al., 2009). It is also worth noting that kinetics may play a central role in real systems, thus rendering the $\mathrm{Hg}$ partition between urban and natural DOM slow (on the range of hours to days). Accordingly, using the Eq. 4 with selected $\alpha$ values, the eventual partitioning of Hg-DOM between WWTP's and Méry's ligands was calculated as follows:

$$
\frac{[\mathrm{Hg}-\mathrm{DOM}]_{\mathrm{W}}}{[\mathrm{Hg}-\mathrm{DOM}]_{\mathrm{M}}} \approx \frac{\sum_{\text {DoM fractions }}[\mathrm{L}]_{\mathrm{W}}\left(\mathrm{K}_{H^{\prime} L}\right)_{\mathrm{W}}}{(\alpha-1) \sum_{\text {DoM fractions }}[\mathrm{L}]_{\mathrm{M}}\left(\mathrm{K}_{H^{\prime} L}\right)_{\mathrm{M}}}
$$

The subscripts $\mathrm{W}$ and $\mathrm{M}$ stand for WWTP and Méry stations, respectively. At $\mathrm{pH} \sim 6.8, \mathrm{I}_{\mathrm{NaCl}}=$ $0.5 \mathrm{M}$ and $\mathrm{T}=25^{\circ} \mathrm{C},[\mathrm{Hg}-\mathrm{DOM}]_{\mathrm{W}}:[\mathrm{Hg}-\mathrm{DOM}]_{\mathrm{M}}$ ratio values decreased from $57,2.4$ down to 0.6 for $\alpha$ of 2, 25 and 100, respectively. These were consistent with the WHAM 6 numerical simulations: the contribution of urban ligands to [Hg-DOM] $([\mathrm{Hg}-\mathrm{DOM}]<10 \mathrm{nM})$ of mixed WWTP and Méry waters decreased from $98 \pm 8 \%, 70 \pm 6 \%$ down to $37 \pm 3 \%$, respectively. As regards the $[\mathrm{Hg}-\mathrm{HPI}]_{\mathrm{W}}:[\mathrm{Hg}-\mathrm{HPO}]_{\mathrm{M}}$ ratio values, these were $32,1.4$ and 0.3 . Despite the uncertainties surrounding these figures, they clearly indicated that urban DOM ligands could eventually dominate the $\mathrm{Hg}$-DOM speciation except under extreme dilutions (i.e. high-water episodes or floods). As a matter of fact, $10 \mathrm{~km}$ downstream from WWTP, during low-water episodes (i.e. $\alpha=4$ ), up to $95 \pm 7 \%$ of $\mathrm{Hg}$-DOM would consist of urban DOM ligands. During high-water episodes (i.e. $\alpha=80$ ), this would represent $43 \pm 5 \%$. Overall, the large discharged volumes of DOM-loaded treated effluents depicted the WWTP as a major source of fresh organic ligands of hydrophilic nature. Due to the discharged amounts and their stronger $\mathrm{Hg}$ binding ability, these urban ligands may durably control the $\mathrm{HgT}_{\mathrm{D}}$ speciation and therefore affect the $\mathrm{Hg}$ bioavailability into the downstream Seine River. 


\section{Acknowledgments}

This research was financially supported by the French National Research Agency (ANR) through the Biomet Project (JC05_59808). The authors would like to thank the Paris Metropolitan Wastewater Authority (SIAAP) for its assistance with the sampling step. Gratitude is also due to J. Harris for editing the manuscript.

\section{References}

Aiken, G.R., McKnight, D.M., Harnish, R., Wershaw, R.L., 1996. Geochemistry of aquatic humic substances in the Lake Fryxell basin, Antarctica. Biogeochem. 34, 157-188.

Benoit, J.M., Mason, R.P., Gilmour, C.C., Aiken, G.R., 2001. Constants for mercury binding by dissolved organic matter isolated from the Florida Everglades. Geochim. Cosmochim. Acta. 65, 4445-4451.

Bloom, N.S., Fitzgerald, W.F., 1988. Determination of volatile mercury species at the picogram level by low-temperature gas chromatography with cold-vapour atomic fluorescence detection. Anal. Chim. Acta. 208, 151-161.

Bloom, N. S., 1989. Determination of picogram levels of methylmercury by aqueous phase ethylation followed by cryogenic gas chromatography with cold vapour atomic fluorescence detection. Can. J. Fish. Aquat. Sci. 46, 1131-1140.

Buffle, J., Deladoey, P., Greter, F.L., Haerdi, W., 1980. Study of the complex formation of copper (II) by humic and fulvic substances. Anal. Chim. Acta. 116, 255-274.

Buffle, J., 1988. Complexation reactions in aquatic systems: an analytical approach. Ellis Horwood, New York.

Cossa, D., Coquery, M., Nakhlé, K., Claisse, D., 2002. Dosage du mercure total et du monomethylmercure dans les organismes et les sédiments marins. Méthodes d"analyse en milieu marin. Technical report. Ifremer, France.

Cossa, D., Averty, B., Bretaudeau, J., Senard, A.S., 2003. Spéciation du mercure dissous dans les eaux marines. Méthodes d"analyse en milieu marin. Technical report. Ifremer, France.

Dong, W.M., Liang, L.Y., Brooks, S., Southworth, G., Gu, B.H., 2009. Roles of dissolved organic matter in the speciation of mercury and methylmercury in a contaminated ecosystem in Oak Ridge, Tennessee. Environ. Chem. 7, 94-102.

Drexel, R.T., Haitzer, M., Ryan, J.N., Aiken, G.R., Nagy, K.L., 2002. Mercury (II) sorption to two Florida Everglades peats: evidence for strong and weak binding and competition by dissolved organic matter released from the peat. Environ. Sci. Technol. 36, 4058-4064.

Filella, M., Quentel, F., Pernet-Coudrier, B., Varrault, G., 2009. Application of a refractory organic matter quantification method to wastewater effluents. Int. J. Env. Anal. Chem. 89, 799-807.

Gasper, J.D., Aiken, G.R., Ryan, J.N., 2007. A critical review of three methods used for the measurement of mercury $\left(\mathrm{Hg}^{2+}\right)$-dissolved organic matter stability constants. App. Geochem. 22, 1583-1597.

Haitzer, M., Aiken, G.R., Ryan, J.N., 2002. Binding of mercury (II) to dissolved organic matter: the role of the mercury-to-DOM concentration ratio. Environ. Sci. Technol. 36, 3564-3570.

Haitzer, M., Aiken, G.R., Ryan, J.N., 2003. Binding of mercury(II) to aquatic humic substances: influence of $\mathrm{pH}$ and source of humic substances. Environ. Sci. Technol. 37, 2436-2441.

Han, S.H., Gill, G.A., 2005. Determination of mercury complexation in coastal and estuarine waters using competitive ligand exchange method. Environ. Sci. Technol. 39, 6607-6615. 
Hesterberg, D.; Chou, J. W.; Hutchison, K. J.; Sayers, D. E. Bonding of $\mathrm{Hg}(\mathrm{II})$ to reduced organic sulfur in humic acid as affected by S/Hg ratio. Environ. Sci. Technol. 2001, 35, 2741-2745.

Herrin, R.T., Andren, A.W., Shafer, M.W., Armstrong, D.E., 2001. Determination of silver speciation in natural waters. 2. Binding strength of silver ligands in surface freshwaters. Environ. Sci. Technol. 35, 1959-1966.

Hsu-Kim, H., Sedlak, D., 2003. Strong Hg(II) complexation in municipal wastewater effluent and surface waters. Environ. Sci. Technol. 37, 2743-2749.

Khwaja, A.R., Bloom, P.R., Brezonik, P.L., 2006. Binding constants of divalent mercury $\left(\mathrm{Hg}^{2+}\right)$ in soil humic acids and soil organic matter. Environ. Sci. Technol. 40, 844-849.

Lamborg, C.H., Tseng, C.M., Fitzgerald, W.F., Balcom, P.H., Hammerschmidt, C.R., 2003. Determination of the mercury complexation characteristics of dissolved organic matter in natural waters with „,reducible Hg"'titrations. Environ. Sci. Technol. 37, 3316-3322.

Lehninger, A.L., 1985. Biochemie. Verlag Chemie, Weinheim.

Ma, H., Allen, H.E., Yin, Y., 2001. Characterization of isolated fractions of dissolved organic matter from natural waters and a wastewater effluent. Water. Res. 35, 985-996.

Merck, 2011. Photometry and test kits. Certificates of quality of Spectroquant $\circledast$ test kits. Catalog number: $\mathrm{Cl}^{-}, 114730 ; \mathrm{Na}^{+}, 100885$ and $\mathrm{NO}_{3}^{-}, 114563$.

Meybeck, M., De Marsily, G., Fustec, E., 1998. La Seine en son bassin. Fonctionnement écologique d'un système fluvial anthropisé. Elsevier, Paris.

Miller, C.L., Mason, R.P., Gilmour, C.C., Heyes, A., 2007. Influence of dissolved organic matter on the complexation of mercury under sulfidic conditions. Environ. Toxicol. Chem. 26, 624-633.

Miller. C.L., Southworth, G., Brooks, S., Liang, L., Gu, B., 2009. Kinetic controls on the complexation between mercury and dissolved organic matter in a contaminated environment. Environ. Sci. Technol. 43, 8548-8553.

Morra, M.J., Fendorf, S.E., Brown, P.D., 1997. Speciation of sulfur in humic and fulvic acids using X-ray absorption near-edge structure (XANES) spectroscopy. Geochim. Cosmochim. Acta 61, 683-688.

National Institute of Standards and Technology (NIST) 2004. Critical constants for metal complexes. Std. Ref. Database 46, U.S. Dept.

Olivella, M.A., Palacios, J.M., Vairavamurthy, A., Río, J.C., Heras, F.X.C., 2002. A study of sulfur functionalities in fossil fuels using destructive- and non-destructive-techniques. Fuel 81, 405-411.

Pernet-Coudrier, B., Clouzot, L., Varrault, G., Rousselot, O., Tusseau-Vuillemin, M.H., Mouchel, J.-M., 2008. Characterization of dissolved organic matter from discharge of a major French wastewater treatment plant and influence of copper toxicity. Chemosphere 73, 593-599.

Pernet-Coudrier, B., Companys, E., Galceran, J., Morey, J., Mouchel, J.-M., Puy, J., Ruiz, N., Varrault, G., Pb-binding to various Dissolved Organic Matter in urban aquatic systems: key role of the most hydrophilic fraction, Geochim. Cosmochim. Acta, submitted July 2010.

Pernet-Coudrier, B., Varrault, G., Dignac, M.-F., Mouchel, J.-M., 2010. Characterisation of dissolved organic matter in Parisian urban aquatic systems: predominance of hydrophilic and proteinaceous structures. Biogeochem. DOI: 10.1007/s10533-0109480-z.

Powell, K.J., Brown, P.L., Byrne, R.H., Gajda, T., Hefter, G., Sjöberg, S., Wanner, H., 2005. Chemical speciation of environmentally significant heavy metals with inorganic ligands. Part 1: the $\mathrm{Hg}^{2+}-\mathrm{Cl}^{-}, \mathrm{OH}^{-}, \mathrm{CO}_{3}{ }^{2-}, \mathrm{SO}_{4}{ }^{2-}$, and $\mathrm{PO}_{4}{ }^{3-}$ aqueous systems. Pure Appl. Chem. 77, 739-800.

Qian, J., Skyllberg, U., Frech, W., Bleam, W.F., Bloom, P.R., Petit, P.E., 2002. Bonding of methyl mercury to reduced sulfur groups in soil and stream organic matter as determined by x-ray absorption spectroscopy and binding affinity studies. Geochim Cosmochim Acta 66, 3873-3885. 
Ravichandran, M., 1999. Interactions between mercury and dissolved organic matter in the Florida Everglades. Ph.D. dissertation, Univ. Colorado.

Ravichandran, M., 2004. Interactions between mercury and dissolved organic matter - a review. Chemosphere 55, 319-331.

Ruttenberg, K.C., Goñi, M.A., 1997. Phosphorus distribution, C:N:P ratios, and $\delta 13 C_{O C}$ in arctic, temperate, and tropical coastal sediments: tools for characterizing bulk sedimentary organic matter. Mar. Geol. 139, 123-145.

Skyllberg, U, Bloom, PR, Qian, J., Lin, CM, Bleam, WF, 2006 Complexation of mercury(II) in soil organic matter: EXAFS evidence for linear two-coordination with reduced sulfur groups. Environ. Sci. Technol. 40(13), 4174-4180.

Skyllberg, U., Xia, K., Bloom, P.R., Nater, E.A., Bleam, W.F., 2000. Binding of mercury (II) to reduced sulfur in soil organic matter along upland-peat soil transects. J. Environ. Qual. 29, 855-865.

Tessier, A., Turner, D.R., 1995. Metal speciation and bioavailability in aquatic systems. John Wiley \& Sons, New York.

Tipping, E., 2002. Cation Binding by Humic Substances. Cambridge University Press, Cambridge.

Tipping, E., 2007. Modelling the interactions of $\mathrm{Hg}(\mathrm{II})$ and methylmercury with humic substances using WHAM/Model VI. App. Geochem. 22, 1624-1635.

Town, R.M., Filella, M., 2000. A comprehensive systematic compilation of complexation parameters reported for trace metals in natural waters. Aquat. Sci. 62, 252-295.

Xia, K.; Skyllberg, U. L.; Bleam, W. F.; Bloom, P. R.; Nater, E. A.; Helmke, P. A. X-ray absorption spectroscopic evidence for the complexation of $\mathrm{Hg}(\mathrm{II})$ by reduced sulfur in soil humic substances. Environ. Sci. Technol. 1999, 33, 257-261.

Yin, Y., Allen, H.E., Huang, C.P., Sanders, P.F., 1997. Interaction of Hg(II) with soil-derived humic substances. Anal. Chim. Acta. 341, 73-82. 
Table 1: Selected chemical characteristics (expressed as measured value \pm one standard error of measurement) of DOM fractions and reference materials used to classify the organic substances included in this study.

\begin{tabular}{|c|c|c|c|c|c|c|c|c|}
\hline $\mathrm{DOM}$ & Nature & [DOC] & $\mathrm{C}: \mathrm{N}$ & $\mathrm{C}: \mathrm{S}$ & $\mathrm{S}$ & $\begin{array}{c}{ }^{*} \text { Org-S } \\
\text { (estimated) }\end{array}$ & $\log K_{\mathrm{HgI}}^{\prime}$ & $\mathrm{L}$ \\
\hline & & $\mathrm{mg} \mathrm{L}^{-1}$ & / & / & $\mathrm{nmol} \mathrm{mgC}^{-1}$ & $\mathrm{nmol} \mathrm{mgC}^{-1}$ & / & $\mathrm{nmol} \mathrm{mgC}^{-1}$ \\
\hline \multirow{3}{*}{ Méry } & $\mathrm{HPO}$ & $1.3 \pm 0.5$ & $17.6 \pm 0.6$ & $120 \pm 15$ & $680 \pm 30$ & 70 & $24.7 \pm 0.1$ & $52.4 \pm 0.3$ \\
\hline & TPI & $0.5 \pm 0.5$ & $11.1 \pm 0.3$ & $70 \pm 4$ & $1260 \pm 60$ & 90 & $24.4 \pm 0.1$ & $19.2 \pm 0.2$ \\
\hline & HPI & $<0.2$ & n.a. & n.a. & n.a. & n.a. & $24.2 \pm 0.1$ & $9.1 \pm 0.1$ \\
\hline \multirow{3}{*}{ WWTP } & $\mathrm{HPO}$ & $12.2 \pm 0.5$ & $11.1 \pm 0.2$ & $56 \pm 2$ & $1,490 \pm 80$ & 310 & $25.4 \pm 0.1$ & $18.7 \pm 0.2$ \\
\hline & TPI & $7.2 \pm 0.5$ & $6.7 \pm 0.1$ & $63 \pm 3$ & $1,330 \pm 60$ & 285 & $25.1 \pm 0.1$ & $50.1 \pm 0.1$ \\
\hline & HPI & $16.6 \pm 0.5$ & $4.2 \pm 0.1$ & $55 \pm 3$ & $1,520 \pm 70$ & 210 & $25.3 \pm 0.1$ & $37.2 \pm 0.4$ \\
\hline \multirow{4}{*}{$\begin{array}{l}\text { Reference } \\
\text { materials }\end{array}$} & SRFA & & $56.4 \pm 6$ & $255 \pm 50$ & $325 \pm 20$ & $140(110)$ & $22.8 \pm 0.3$ & $324 \pm 1$ \\
\hline & & {$[25-75]$} & & & & & & \\
\hline & SRHA & & $52.5 \pm 5$ & $260 \pm 50$ & $320 \pm 20$ & $170(220)$ & $24.4 \pm 0.1$ & $61.2 \pm 0.1$ \\
\hline & Fluka & n.a. & $89.0 \pm 15$ & $99 \pm 8$ & $840 \pm 40$ & 720 & $24.7 \pm 0.1$ & $8.3 \pm 0.3$ \\
\hline
\end{tabular}


Table 2: WHAM 6 computed Hg-DOM partition between natural and urban DOM fractions. Data were obtained at $\mathrm{pH} \sim 6.8, \mathrm{INaCl}=0.5 \mathrm{M}$ and $\mathrm{T}=25^{\circ} \mathrm{C}$ using experimentally determined $\mathrm{K}^{\prime} \mathrm{HgL}$ and $\mathrm{L}$ values. They account for the eventual Hg-DOM partition shift during increasing dilutions of WWTP effluents with riverine waters like Méry's.

\begin{tabular}{|c|c|c|c|c|c|c|c|c|}
\hline \multirow[b]{3}{*}{$\mathrm{DOM}$} & \multirow[b]{3}{*}{ Nature } & \multicolumn{7}{|c|}{ Hg-DOM (\%) } \\
\hline & & \multicolumn{2}{|c|}{ Dilution factor $(\alpha)$} & \multirow{2}{*}{$\begin{array}{c}\alpha=2 \\
\text { (WWTP } \\
\text { output) }\end{array}$} & \multirow{2}{*}{$\begin{array}{c}\alpha=4 \\
\text { (low } \\
\text { waters) }\end{array}$} & \multirow{2}{*}{$\begin{array}{c}\alpha=25 \\
\text { (average } \\
\text { dilution) }\end{array}$} & \multirow{2}{*}{$\begin{array}{c}\alpha=80 \\
\text { (high } \\
\text { waters) }\end{array}$} & \multirow{2}{*}{$\begin{array}{c}\alpha=100 \\
\text { (flood } \\
\text { events) }\end{array}$} \\
\hline & & $\begin{array}{l}\text { Méry } \\
\text { waters }\end{array}$ & $\begin{array}{l}\text { WWTP } \\
\text { effluents }\end{array}$ & & & & & \\
\hline \multirow{3}{*}{ Méry } & $\mathrm{HPO}$ & $94 \pm 7$ & l & $2 \pm 1$ & $5 \pm 1$ & $28 \pm 2$ & $54 \pm 4$ & $59 \pm 5$ \\
\hline & TPI & $5 \pm 1$ & / & $<0.1$ & $0.3 \pm 0.2$ & $1.0 \pm 0.7$ & $3 \pm 1$ & $3 \pm 1$ \\
\hline & HPI & $0.7 \pm 0.5$ & / & $<0.1$ & $<0.1$ & $0.2 \pm 0.1$ & $0.4 \pm 0.2$ & $0.4 \pm 0.2$ \\
\hline \multirow{3}{*}{ WWTP } & $\mathrm{HPO}$ & / & $25 \pm 3$ & $24 \pm 2$ & $24 \pm 2$ & $18 \pm 1$ & $11 \pm 1$ & $9 \pm 1$ \\
\hline & TPI & / & $22 \pm 2$ & $21 \pm 1$ & $20 \pm 1$ & $15 \pm 1$ & $9 \pm 1$ & $8 \pm 1$ \\
\hline & HPI & / & $53 \pm 4$ & $53 \pm 4$ & $51 \pm 3$ & $38 \pm 3$ & $23 \pm 2$ & $20 \pm 2$ \\
\hline$[\mathrm{Hg}-\mathrm{DOM}]_{\mathrm{W}}$ & & & & & & & & \\
\hline contribution (\%) & & 0 & 100 & $98 \pm 8$ & $95 \pm 7$ & $70 \pm 6$ & $43 \pm 5$ & $37 \pm 3$ \\
\hline
\end{tabular}




\section{Figures}

Figure 1: Langmuir isotherms. The conditional (i.e. $\mathrm{pH} \sim 6.8, \mathrm{I}_{\mathrm{NaCl}}=0.5 \mathrm{M}, \mathrm{T}=25^{\circ} \mathrm{C}$ ) stability constants of $\mathrm{Hg}$-DOM complexes were assessed by gauging the water-methylene chloride $\mathrm{Hg}$ partitioning following $\mathrm{Hg}\left(\mathrm{NO}_{3}\right)_{2}$ additions in the presence of $0.5 \mathrm{M}$ chlorides and $1 \mu \mathrm{g}_{\mathrm{DOM}} \mathrm{L}$ ${ }^{1}$ of every single organic substance (i.e. hydrophobic, HPO; transphilic, TPI; hydrophilic, HPI DOM fractions or reference materials).

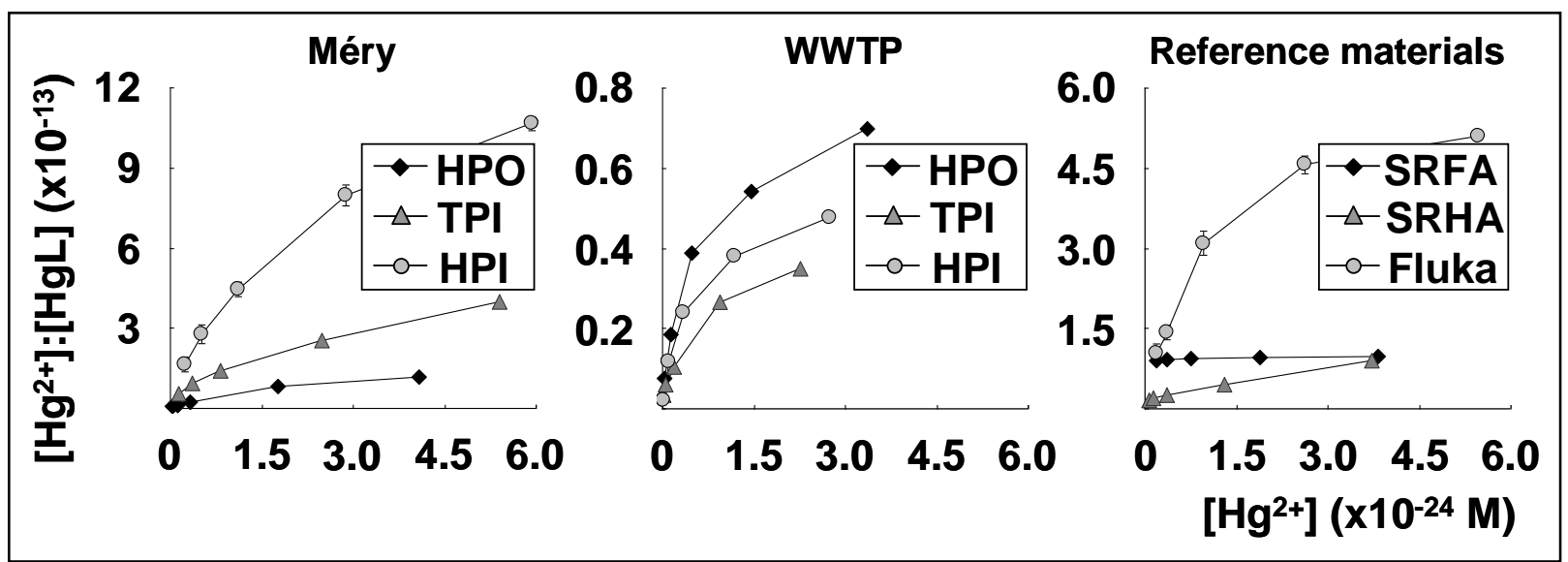

Figure 2: a) Molar $\mathrm{C}: \mathrm{N}$ ratios plotted against $\mathrm{C}: \mathrm{S}$ ratios for all DOM fractions and reference materials, b) estimated percentages of total organic sulfur in the reduced form [Org-S $S_{R E D}: S$ (\%)] in relation to $\mathrm{C}: \mathrm{N}$ ratios. The error bars represent standard errors of measurements.

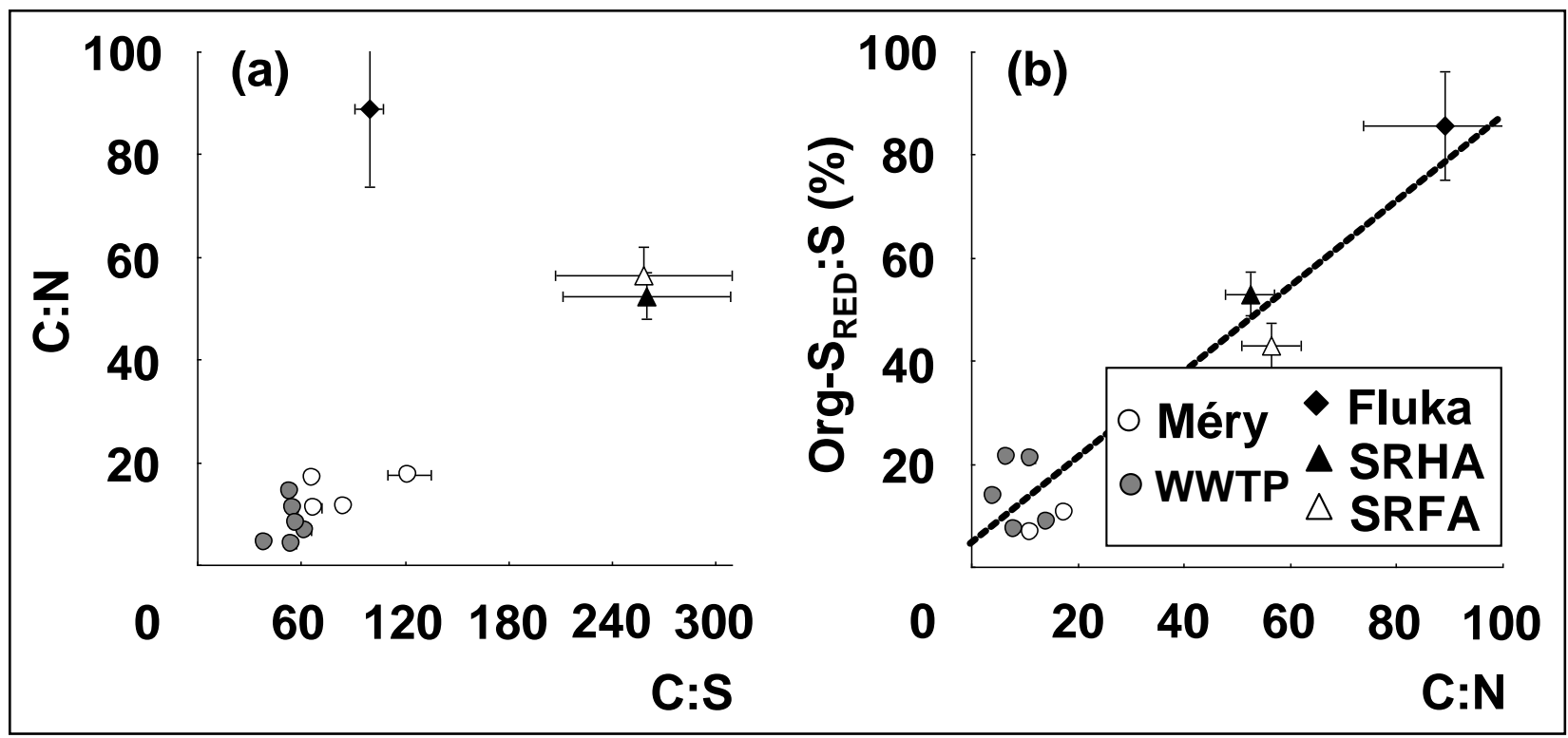


Figure 3: Log conditional (i.e. $\mathrm{pH} \sim 6.8, \mathrm{I}_{\mathrm{NaCl}}=0.5 \mathrm{M}, \mathrm{T}=25^{\circ} \mathrm{C}$ ) stability constants for organic complexes with $\mathrm{Hg}^{2+}$ (Log $K_{\mathrm{HgL}}^{\prime}$ ) in relation to DOM enrichments in: a) total organic nitrogen, and b) total organic sulfur. The asterisk indicates a data point not considered during the data analysis. The error bars represent standard errors of measurements.

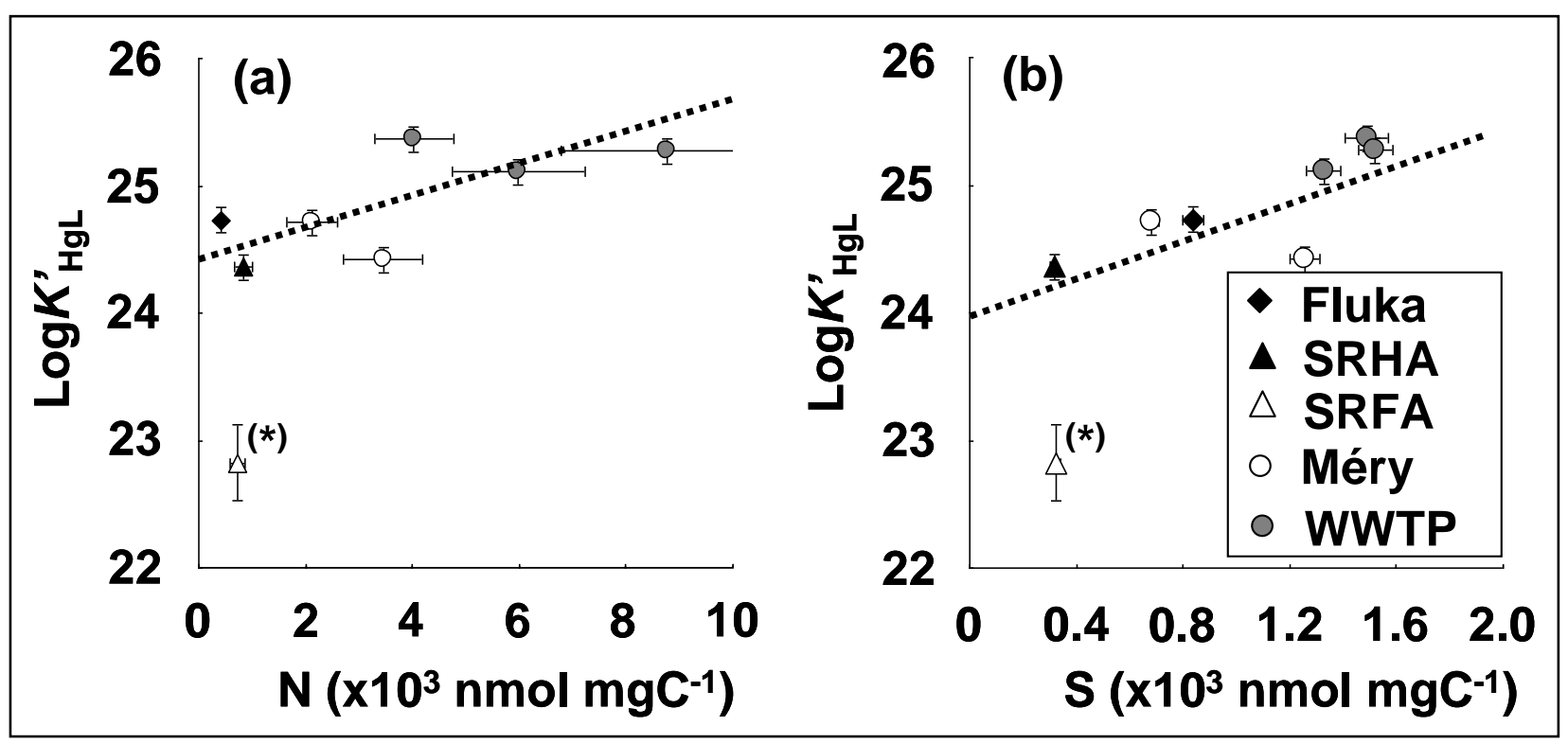

